\section{Problems at Albert Einstein}

SIR-We, the undersigned faculty members of the Albert Einstein College of Medicine, are responding to the article by Joseph Palca (Nature 338, 192; 1989). It is not our intention to comment upon the specific issues in this article. Our concern relates to the statement that "Einstein has had a poor track record in its attitude towards female faculty".

Having been associated with the Albert Einstein College of Medicine in New York for many years, some of us since its inception, we recognize that our opportunities and achievements in science, including the President's Medal of Science and membership of leading societies, such as the National Academy of Sciences, as well as of National Institutes of Health study sections and councils, derive to a large extent from our positive associations with Einstein. Since the college opened its doors in 1955 , it has upheld its humane policy of equal opportunity for all, regardless of race, creed, political beliefs or sex. In fact, there is a high proportion of women among the Einstein faculty, including those in senior rank. Women did and do serve as departmental chairpersons. It would be difficult to find an institution with a better track record in its attitude towards female faculty than the Albert Einstein College of Medicine.

Barbara K. BIRShtein (Professor of Cell Biology), Olga O. Blumenfeld (Professor of Biochemistry), SUSAN B. HORWITZ (Professor and Chair of Molecular Pharmacology), Gertie F. MARX (Professor Emerita of Anesthesiology), ISABELLE RAPIN (Professor of Neurology and Pediatrics), BERTA V. SCHARRER (Distinguished University Professor Emerita of Anatomy and Structural Biology), LADONNE H. SCHULMAN (Professor of Developmental Biology and Cancer), Pamela M. Stanley (Professor of Cell Biology), Salome G. Waelsch (Distinguished University Professor Emerita of Molecular Genetics), ORA M. Rosen (Visiting Professor of Molecular Pharmacology, Former Professor and Chair of Molecular Pharmacology).

Albert Einstein College of Medicine, Bronx, NY 10461, USA

SIR-The National Coalition would like to comment on the seemingly 'spontaneous' letter (above) signed by 10 women faculty of the Albert Einstein College of Medicine of the Yeshiva University supporting the college as non-discriminatory.

The letter flatly asserts that there is "a high proportion of women among the faculty at Einstein, including those in senior rank". It makes no statement about their salaries in comparison to male colleagues. We find the omission significant and glaring since, in the case of Sobel vs. Yeshiva University, a class action case involving 40-60 women, the Court of Appeals found "blatant, systemic, sex-based wage discrimination". This case has been in court for 11 years and has cost the university more than $\$ 2$ million so far.

The assertion that women "do serve as departmental chairpersons" suffers from the same lack of comparison.

What perhaps is more indicative of the sincerity motivating this letter is the signature of Dr Olga O. Blumenfeld, who is on record in the faculty senate minutes as saying that the Sobel case accompanied much by drawing attention "to prior unequal treatment of Women Faculty at Einstein and in other medical schools and that Einstein has sought to correct salary inequities".

The letter's statement that "since 1955, (Einstein) has upheld its humane policy of equal opportunity for all," suggests that the signatories are attempting to placate an increasingly angry public, including several important women philanthropists, who are angry at the pattern of sexual discrimination at Einstein, an issue which has been raised anew by the Heidi Weissmann case.

The minutes of the faculty senate reveal outrage at the continuing waste of university resources and anger with the continuing pattern of discrimination. Dr Blumenfeld herself, reporting to the senate that Yeshiva was now taking the case to the Supreme Court, said with some exasperation, "I don't want to be involved in this case any more. . I only want to express my own disappointment that the administration has never answered our resolution (urging settlement of the Sobel case) and never informed the senate why they are taking the actions they are taking". In another place in the minutes, Dr Blumenfeld says that ". . . the school, if it reached a settlement, would gain in reputation as a progressive institution".

The Coalition suggests that this supportive letter for Einstein has more to do with faculty concern about bad press than with the reality of discriminatory behaviour at their own institution.

\section{LEONARD MINSKY \\ National Coalition for Universities in the Public Interest,}

\section{Dupont Circle}

Washington, DC 20036, USA

SIR-I was given by Dean Purpura of the Albert Einstein School of Medicine a copy of a letter signed by 10 female faculty members at Einstein, written in response to an article by Joseph Palca about a plagiarism dispute between two faculty members at Albert Einstein School of Medicine. The signatories stated that Einstein gives equal opportunity to women, and has a good track record in its attitude toward women

I represent a philanthropic foundation that did not give an important contribution to this institution over three years ago because of the then 10-year-old Sobel vs. Yeshiva University case which was eating up funds that could be used for a better purpose. This case is still in litigation.

I find the letter signed by the ten female faculty members hard to understand. The faculty senate minutes of 24 June 1987, 10 February 1988, 9 March 1988 and 11 May 1988 paint a very different picture. Dr Olga Blumenfeld, who signed the letter to Nature, expresses in all of these verbatim transcribed minutes her intense frustration at the failure to settle this case, at the excessive university spending (close to $\$ 2$ million by 24 June 1987) and the lack of response on the part of the university to the faculty senate motions to negotiate a settlement.

Reflecting on Dr Blumenfeld's exasperation, I can only wonder why she signed the letter sent to you. As a philanthropist, I am further encouraged by this situation to investigate carefully all institutions that request funding, and to do my best to persuade other philanthropic organizations and individuals to demand that the institutions they support conform to the highest ethical and moral standards before they make such gifts and donations.

RITAJ. KAPLAN

Rita J. and Stanley H. Kaplan

Foundation, Inc.

866 United Nations Plaza,

Suite 547,

New York, New York 10017, USA

\section{No photocopying}

SIR-There is a further point relevant to the discussion about the merits of photocopying research papers or sending for reprints. At the University of Manchester, an agreement between the university and the Copyright Licensing Agency forbids the photocopying of more than one article from a single issue of a journal. I do not know how many other institutions are subject to similar regulations, but the implication here is clear: if copies of more than one article from a single issue are to be obtained, it must be by sending for reprints.

Department of Mathematics,

D. L. Moss

The University,

Manchester M13 9PL, UK

\section{Two birds. . .}

SIR-Will it soon be possible to achieve superconductivity and fusion at the same temperature?

Computing Service,

ROBERT HILL

University of Leeds,

Leeds LS2 9JT, UK 